\title{
INTRODUCTION: DIVERSITY, INTEGRATION AND CITIZENSHIP
}

\author{
ADAM BERRYMAN AND KATE MITCHELL
}

This issue of Humanities Research had its genesis in the European Diaspora Research Network, an initiative of the National Europe Centre at The Australian National University and Victoria University in Melbourne. ${ }^{1}$ The network was founded with the aim of connecting scholars from a variety of disciplines with relevant policy practitioners and migrant-community leaders to facilitate collaborative research. The primary activities of the network culminated in 2006, with a capstone international conference that explored the links and synergies between European diasporic communities in Australia and the continuing processes of European integration.

One of the core research themes of the network was citizenship. More specifically, researchers engaged with the changing nature of citizenship in an era of increased international mobility, a progressively globalised economy and the formation of supranational political entities such as the European Union. In the current context older questions were revisited with renewed urgency. How do political discourses shape national identities? What are the most effective means of integrating cultural, ethnic and religious minorities? What type, or degree, of (political) recognition aids integration and what level of recognition becomes counterproductive to social cohesion, provoking divisions within host societies?

The articles in this volume analyse citizenship with a view to better understanding its potential to accommodate ethnic diversity and promote social integration. In doing so, they raise and seek to address a series of questions regarding the political uses of citizenship and its legitimising function for individuals, minority groups and political authorities. To this end, the volume can be loosely divided into two parts. The first addresses 'topdown' approaches to citizenship that have developed within Europe and Australia, examining the ways in which political constructs of belonging are translated into policy and law. The second section reflects a more 'bottom-up' analysis of the response of European diasporas to the conditions and provisions of Australian society and citizenship.

In the first article, Dora Horvath looks at citizenship within the European integration project. The European Union (EU) has introduced a multilevel citizenship regime, aimed at enhancing supranational legitimacy and developing a stronger sense of European identity. The article examines the constitutional basis of EU citizenship through a cosmopolitan lens, identifying the different streams of cosmopolitan thought within the treaties that form the legal basis for European integration. Tra- 
cing an arc of cosmopolitan philosophy from Kant to Habermas, the article highlights some of the reasons why the European Union has become the case study par excellence for cosmopolitanists in the past two decades. It points out, however, that postmodern conditions require new forms of citizenship that accommodate not just cosmopolitan universalism, but multiculturalism - a diversity of political and cultural traditions - and transnationalism, the active engagement of citizens in a postnational context. Although there is much within the treaties to encourage a cosmopolitan understanding of EU citizenship, Horvath explains why it has done little to legitimise Brussels elites or build support for deeper political integration in Europe.

In their article 'Citizenship and identity in diverse societies', Mark Nolan and Kim Rubenstein explore the recent changes to Australian citizenship law and its impact on the acceptance of blended identities in Australia. Drawing on legal analysis of Australian citizenship and psychological research on identity, they argue that recent citizenship policy reforms represent a backward step in terms of understanding complex, blended identities in Australia. They question the assumption, implicit within the new citizenship law, that the testing of language proficiency and civics knowledge, together with the endorsement of Australian values, will successfully encourage the formation of simple, single Australian national identity-and they further contest the desirability of such an outcome. This article highlights some of the shortcomings of the 2007 Australian Citizenship Act, notably the inconsistency between the introduction of testing to encourage a singular notion of national identity and the established legal provi- sion for dual or multiple citizenship. The article's psycho-legal approach underlines the legitimising effect of legal processes relating to citizenship, providing insights as to how the application for and acquisition of citizenship in Australia works to (de)-legitimise an individual's desired selfdefinition. In doing so, it provokes a series of broader questions about the political uses of citizenship and its relationship with identity formation.

In keeping with the European Diaspora Research Network's promotion of interdisciplinary collaboration, the third article in this volume takes a historical perspective. Making interwar Austria her case study, Julie Thorpe subverts the conventional distinction between 'authoritarian' and 'fascist' states, positioning herself among a number of historians who suggest that it is more useful to plot these states on a spectrum of radical right-wing tendencies. Such an approach focuses on processes rather than outcomes and approaches fascism as an extension of other policies that seek to control the citizens of a given state. To this end, her article examines public debates about the 1935 proposal for an Austrian population index, modelled on fascist Italy's legislation. Thorpe situates Austria within a particular constellation of post-imperial state-building discourses, including exclusionary ultra-nationalism and aggressive, racially motivated population politics, which was a stimulus for and reaction to waves of intracontinental migration. By highlighting the roots of Austria's extreme nationalist discourse and the population policy it prompted, Thorpe illustrates the political foundations of European intolerance in the twentieth century. Placed alongside the other articles in this volume, Thorpe's 
historical perspective enables us to identify residual elements of this nationalist project in contemporary political discourses regarding immigration and multiculturalism.

In the final two articles, the focus shifts to immigrant communities in Australia. These articles contribute to recent research that challenges the assumption that a diaspora's connection to their country of origin weakens over time. Instead, several scholars have recently suggested that in an era of globalisation many diasporas are now redefining and reinforcing their identification with their homeland (see, for example, Dufoix 2008; Fullilove 2008). Vesna Drapac aptly illustrates this in her examination of the experience of Croatian immigrants in the context of debates about Australian multiculturalism. Focusing on those who arrived in the first two waves of post-1945 immigration, she argues that the active citizenship and associational practices of this group led to their successful integration into Australian society, but that this was coupled with the retention of elements of Croatian cultural identity. She suggests that the mobilisation of the Croatian community in Australia in response to the political upheaval and violence engendered by the collapse of Yugoslavia in the 1990s demonstrates the extent to which this group attaches themselves to the democratic ideals and processes of their adoptive country. Significantly, Drapac notes this group's paradoxical success in gaining greater recognition for a Croatian national identity before the official recognition of the Croatian State by the Australian Government or the international community.

The final article, Stefan Markowski's 'Citizenship and integration: a snapshot of the Polish migrant community in Australia', draws on survey and census data to argue that Polish immigrants have blended well into Australian society. The data presented here suggest that Polish immigrants to Australia claim a strong sense of Australian national identity and that they score well on traditional measures of integration, such as language proficiency and citizenship uptake. Markowski points out that, in this sense, Polish immigrants represent the type of migration that Australian policymakers have sought to attract. He acknowledges that there is still a tendency for Polish migrants and their descendents to retain or seek Polish citizenship, the value of which has increased since Poland joined the European Union. He argues, however, that this is more a matter of convenience - to facilitate ease of travel between Europe and Australia, for instance - rather than any sense of political belonging or overt loyalty to the Polish nation, supported by the fact that there has been minimal return migration to Poland.

Markowski engages directly with the argument put forward by Nolan and Rubenstein in this volume regarding the recent reforms of Australian citizenship policy. He acknowledges that the engineering of citizenship as a tool primarily for migrant integration has to some extent devalued citizenship for the broader Australian community but is much less critical of the notion of a 'uniform' national identity promoted via the 2007 Australian Citizenship Act. He argues that some sense of uniformity is logically necessary, but need not be considered intolerant of social diversity or mutually exclusive with hybrid, or blended, identity. 
What this issue of Humanities Research seeks to do, then, is draw together a range of disciplinary approaches and multivalent perspectives on the important role citizenship plays - symbolically, socially and legally - in integrating a state's population and shaping the identity of individuals, communities and nations. Although the articles articulate diverse positions on these issues, they nonetheless gravitate to a central concern: in an age of globalisation and multiculturalism, how can democratic states, or supranational constellations of states, uphold a notion of citizenship that fosters social cohesion while also legitimising diversity?

\section{REFERENCES}

Dufoix, Stephane 2008, Diasporas, University of California Press, Berkeley.

Fullilove, Michael 2008, World Wide Webs: Diasporas and the international system, Lowy Institute for International Policy, Sydney.

\section{ENDNOTES}

1 The network was funded by an EU Jean Monnet Reflection Activities Grant (No. 2005 1894/001-001), 'European Diaspora Research Network in Australia', and by The Australian National University and Victoria University. 